\title{
MOTIVASI ORANG TUA MENYEKOLAHKAN ANAK DI KB AISYIYAH 30 SURABAYA
}

\author{
Siti Sholikhah, Wahano, Tri Kurniawati \\ Mahasiswa Pendidikan Guru Pendidikan Anak Usia Dini \\ Universitas Muhammadiyah Surabaya \\ Email : alifwildan53@gmail.com,wwwahono7@gmail.com, \\ trikurniawati@fkip.um-sby.ac.id
}

\begin{abstract}
ABSTRAK
Latar belakang pemilihan penelitian karena KB Aisyiyah berada di lokasi yang mayoritas penduduknya berfaham Nahdlotul Ulama dan bersuku Madura. Hubungan orang tua dan anaknya sangat mempengaruhi keberhasilan belajar anak, tentu saja pada tahap awal orang tua harus memperhatikan minat anaknya dan sesuai dengan bakat yang dimiliki anaknya. Karena Orang tua memiliki tanggung jawab terhadap pendidikan anaknya maka motivasi orang tua dalam memilih sekolah bagi anaknya pada usia dini menjadi salah satu penentu di masa depan. Penelitian ini bertujuan untuk 1).mengetahui bagaimana alasan orang tua memilih sekolah untuk anak usia dini di Kelompok Bermain Aisyiyah 30 Surabaya. 2). Untuk mengetahui bagaimana motivasi orang tua terhadap pemilihan sekolah untuk anak usia dini di Kelompok Bermain Aisyiyah 30 Surabaya. Metodologi Penelitian menggunakan jenis penelitian kualitatif dengan desain case study. Tekhnik pengumpulan data pada penelitian ini menggunakan observasi, wawancara dan dokumentasi. Hasil penelitian menyatakan bahwa alasan orang tua termotivasi memilih sekolah untuk anak usia dini di Kelompok Bermain Aisyiyah 30 Surabaya adalah karena dekat dengan rumah, untuk penanaman agama sejak usia dini, dan memperoleh pendidikan terbaik dengan biaya yang terjangkau.
\end{abstract}

Kata kunci: Motivasi orang tua,Sekolah, Anak Usia Dini.

\begin{abstract}
The selection background of the study was because KB Aisyiyah was located in majority community of Nahdlotul Ulama and Madurese. The relationship of parents and children greatly influenced the success of children's learning so that in this early stages parents must pay attention to their children's interests and according to their talents. Because parents have responsibility for their education, parent's motivation to choose a school for their children at an early age is one of the determinants factor in the future. This study aimed to 1). knowing how the parents chose schools for early childhood in the Aisyiyah Play Group 30 Surabaya. 2). To find out how parents' motivation towards school selection for early childhood in Aisyiyah Play Group 30 Surabaya. Research methodology used a type of qualitative research with a case study design. The data collection techniques in this study used observations, interviews and documentations. The results of the study stated that the reasons for parents' motivation to choose schools for early childhood in Aisyiyah Play Group 30 Surabaya Group were because they were close to home, to educate religion from an early age, and to get the best education at an affordable cost.
\end{abstract}

Keywords: Parents' motivation,School, early childhood.

\section{PENDAHULUAN}

Masa usia dini adalah masa emas perkembangan anak dimana semua aspek perkembangan dapat dengan mudah distimulasi. Periode emas ini hanya berlangsung satu kali 
sepanjang rentang kehidupan manusia, oleh karena itu pada masa usia dini perlu dilakukan upaya pengembangan menyeluruh yang melibatkan aspek pengasuhan, kesehatan, pendidikan, dan perlindungan. Salah satu upaya yang dapat dilakukan dalam rangka pengembangan potensi tersebut adalah dengan program pendidikan yang terstruktur, yaitu satuan atau program PAUD. Peraturan Menteri Pendidikan dan Kebudayaan Republik Indonesia nomor 137 tahun 2014 bab 1 pasal 1 butir 11 menyatakan bahwa satuan atau program PAUD adalah layanan PAUD yang dilaksanakan pada suatu lembaga pendidikan dalam bentuk Taman Kanak-kanak (TK)/Raudataul Athfal (RA)/Bustanul Athfal (BA), Kelompok Bermain (KB), Taman Penitipan Anak (TPA), dan satuan PAUD sejenis (SPS).

Menurut UU No. 20 Tahun 2003 tentang Sistem Pendidikan Nasional Bab 1, pasal 1, butir 14 dan di dalam Peraturan Menteri Pendidikan dan Kebudayaan Republik Indonesia nomor 137 tahun 2014 bab 1 pasal 1 butir 10 serta Permendikbud RI nomor 146 tahun 2014 pasal 1 dinyatakan bahwa "Pendidikan Anak Usia Dini adalah suatu upaya pembinaan yang ditujukan kepada anak sejak lahir sampai dengan usia enam tahun yang dilakukan melalui pemberian rangsangan pendidikan untuk membantu pertumbuhan dan perkembangan jasmani dan ruhani agar anak memiliki kesiapan dalam memasuki pendidikan lebih lanjut".Sedangkan pada pasal 28 tentang (PAUD) pendidikan anak usia dini dinyatakan bahwa pendidikan anak usia dini diselenggarakan sebelum jenjang pendidikan dasar, dapat diselenggarakan melalui jalur pendidikan formal, nonformal, dan atau informal.

Secara umum, tujuan pendidikan anak usia dini adalah mengembangkan berbagai potensi anak sejak dini sebagai persiapan untuk hidup dan dapat menyesuaikan diri dengan lingkungannya. Pendidikan anak pun bisa dimaknai sebagai usaha mengoptimalkan potensi-potensi luar biasa anak yang bisa dibingkai dalam pendidikan, pembinaan terpadu, maupun pendampingan. Terlebih bahwa anak usia dini masih dalam masa-masa keemasan.

Kuantitas suatu sekolah tidak mutlak menjadi ukuran bahwa sekolah tersebut berhasil mencetak siswa yang cerdas, berakhlak mulia dan terampil, dibalik semua itu dituntut peran serta orang tua dan guru, sekaligus masyarakat untuk ikut serta membawa lingkungan pendidikan yang bernuansa ke Islaman. Tentu saja titik akhir semua itu diharapkan sekolah dapat mencetak generasi bermutu dan berakhlak mulia sekaligus menjadi panutan masyarakat sekitarnya, karena di masa mendatang generasi sekaranglah yang diharapkan menjadi penerus cita-cita dan harapan orang tua sekarang. 
Pada zaman sekarang para orang tua ingin membuktikan apa saja yang telah diterima anaknya dalam mengikuti proses pendidikan dan pengajaran terutama di sekolah atau lembaga pendidikan lainnya. Sejalan dengan itu pula UndangUndang Sistem Pendidikan Nasional pasal 7 ayat 1 menjelaskan bahwa Orang tua berhak berperan serta dalam memilih satuan pendidikan dan memperoleh informasi tentang perkembangan pendidikan anaknya. Tersebut dalam Peraturan Menteri Pendidikan dan Kebudayaan Republik Indonesia nomor 137 tahun 2014 bab 3 pasal 7 butir 5 menyatakan bahwa pencapaian pertumbuhan dan perkembangan anak yang optimal membutuhkan keterlibatan orang tua dan orang dewasa serta akses layanan PAUD yang bermutu. Kelompok Bermain Aisyiyah 30 Surabaya adalah salah satu wadah pendidikan anak usia dini yang berbasis Islam.

Anak adalah perhiasan dan penghias rumah tangga.Tangisnya menjadi nyanyi yang merdu buat ayah dan ibunya, kakek dan neneknya.Tawanya menjadi pesona yang menarik.Kemanjaan dan tingkahnya menjadi pelipur kedukaan dan pemulih kelelahan.Sakitnya bisa menyebabkan orang tuanya bersusah hati dan bisa semalam suntuk tidak tidur.Betapapun beratnya, tidak membuat orang tuanya lelah, kesal, atau benci tetapi sebaliknya semakin sayang bahkan memelas karena sedih dan kasihan.Tanpa anak, orang tua merasa sepi karena tidakramai dengan suara perhiasan dan penghias rumah tangga.

Orang tua memiliki tanggung jawab yang besar bagi terselenggaranya pendidikan, bahkan di tangan orang tualah pendidikan anak ini dapat terselenggarakan. (Riadi, dkk:2017) mengutarakan tentang tanggung jawab pendidikan yang harus dipikul orang tua adalah sebagai berikut:

1) Memelihara dan membesarkan anak bentuk yang paling sederhana dari tanggung jawab setiap orang tua dan merupakan dorongan alami untuk mempertahankan kelangsungan manusia.

2) Melindungi dan menjamin keselamatan baik jasmani maupun rohani dasri berbagai gangguan penyakit, dari penyelewengan kehidupan, dan dari tujuan hidup agama yang dianutnya.

3) Member pengajaran dalam arti luas, sehingga anak memperoleh peluang untuk memiliki pengetahuan dan kecakapan seluas dan setinggi mungkin dicapainya.

4) Membahagiakan anak, baik dunia maupun akhirat sesuai dengan pandangan dan tujuan hidup manusia.

Peran orang tua dalam membentuk kepribadian anak sejak usia dini diabadikan Allah Swt dalam al-Qur'an surat Luqman ayat 13-19 karena setiap orang tua hendaknya 
memberikan pendidikan kepada anaknya sejak dini tentang:

1) Membekali Tauhid yang mantap

2) Mendidik agar berbakti kepada kedua orang tua

3) Menanamkan rasa tanggungjawab

4) Membiasakan shalat, amar makruf dan nahi mungkar

5) Menanamkan kesabaran

6) Menjauhkan sifat angkuh dan sombong

7) Memupuk kesederhanaan

Banyak faktor yang mempengaruhi orang tua dalam memilih sekolah untuk anak usia dini. Menurut Sugiharto dalam Saputri (2016) menjelaskan faktor-faktor yang mempengaruhi belajar yaitu, faktor internal dan faktor eksternal.

a. Faktor Internal

Faktor internal adalah faktor yang ada dalam diri individu yang sedang belajar. Adapun faktor intenal meliputi jasmaniah (kesehatan dan cacat tubuh) dan psikologi yang meliputi intelegensi, perhatian, minat, bakat, kematangan, dan kelelahan.

b. Faktor eksternal

Faktor eksternal merupakan faktor yang ada dari luar individu. Faktor tersebut meliputi faktor keluarga, faktor sekolah dan faktor masyarakat. Faktor keluarga meliputi cara orang tua mendidik, relasi antar orang tua, dan latar belakang kebudayaan. Faktor sekolah yang mempengaruhi belajar meliputi, metode mengajar, kurikulum, relasi guru dengan siswa, relasi antar siswa, disiplin sekolah, pelajaran dan waktu sekolah, standar pelajaran, dan keadaan gedung, metode belajar dan tugas rumah. Sedangkan faktor masyarakat meliputi kegiatan siswa dalam masyarakat, teman bergaul, bentuk kehidupan dalam masyarakat dan media massa.

Dari beberapa uraian di atas maka dapat disimpulkan bahwa faktor-faktor yang mempengaruhi orang tua dalam menyekolahkan anak yaitu motivasi intrinsik dan motivasi ekstrinsik.

a. Motivasi intrinsik

Motivasi intrinsik adalah dorongan yang bersumber dari dalam diri individu. Motivasi intrinsik meliputi:

1) Kebutuhan

Pada dasarnya seseorang melakukan sesuatu karena dilandasi adanya kebutuhan untuk mencapai suatu tujuan. Menurut Fuad dalam Saputri (2016) bahwa kebutuhan merupakan unsur-unsur yang dibutuhkan oleh manusia dalam mempertahankan keseimbangan fisiologis maupun psikologis.

2) Harapan

Harapan merupakan anganangan dari seseorang terhadap hasil yang diinginkan. 
Menurut Uno dalam Saputri (2016) dalam teori harapan didasarkan pada keyakinan bahwa orang dipengaruhi oleh perasaan mereka tentang gambaran hasil tindakan mereka. Kaitanya dengan penelitian ini, harapan orang tua terhadap hasil dari pendidikan anak yang telah dilakukan.

\section{b. Motivasi ekstrinsik}

Motivasi ekstrinsik adalah dorongan yang muncul dari luar individu. Motivasi ekstrinsik meliputi:

1) Anak

Dalam penelitian ini anak sebagai faktor ekstrinsik dari orang tua karena anak menjadi subjek belajar dan menjadi objek dalam penelitian.

2) Sarana dan prasarana

Kondisi yang mempengaruhi motivasi orang tua menyekolahkan anak adalah fasilitas yang dimiliki pihak sekolah yang menunjang perkembangan anak akan memperkuat motivasi orang tua.

3) Guru

Metode pengajaran yang digunakan oleh guru menjadi salah satu faktor pendorong orang tua.

Adapun tujuan dari penelitian ini adalah: (1) Mendiskripsikan bagaimana pengelolaan di Kelompok Bermain Aisyiyah 30 Surabaya; (2) Mendiskripsikan bagaimana motivasi orang tua terhadap pemilihan sekolah untuk anak usia dini di Kelompok Bermain Aisyiyah 30 Surabaya.

\section{METODE PENELITIAN}

Dalam penelitian ini, penulis menggunakan pendekatan kualitatif dengan desain penelitian case study. Desain case study yaitu bentuk penelitian yang mendalam tentang suatu aspek lingkungan sosial termasuk manusia di dalamnya (Nasution, 2007:27). Case study dapat dilakukan terhadap seorang individu, sekelompok individu, segolongan manusia, lingkungan hidup manusia atau lembaga sosial.

Tempat penelitian ini dilakukan di Kelompok Bermain KB Aisyiyah 30 yang berada di lokasi Jalan Dukuh Bulak Banteng Gang Perintis Utama 2A/1 Kelurahan Bulak Banteng Kecamatan Kenjeran Kota Surabaya. Waktu penelitian dilakukan selama 4 bulan, yaitu bulan Januari 2019 sampai bulan April 2019. Sedangkan pengumpulan data dalam pelaksanaan penelitian ini, peneliti menggunakan pengumpulan data dari hasil observasi langsung yang dilakukan terhadap orang tua di KB Aisyiyah 30 Kenjeran Surabaya. Teknik pengumpulan data dalam penelitian ini adalah observasi, wawancara dan dokumentasi.

Dalam penelitian ini, penulis menggunakan model analisis data perbandingan tetap (Constant Comparative Method) karena dalam analisis data, secara tetap membandingkan satu datum dengan datum yang lain, dan kemudian 
secara tetap membandingkan kategori dengan kategori lainnya. Secara umum analisis datanya mencakup: reduksi data, kategori data, sintesisasi, dan diakhiri dengan menyusun hipotesis kerja (J.Moleong, 2007: 288).

\section{HASIL PENELITIAN}

Hasil wawancara yang dilakukan terhadap 18 orang tua siswa menunjukkan tiga motivasi yang diungkapkan orang tua dalam menyekolahkan anaknya di KB Aisyiyah 30 Surabaya, yaitu: (1) Keinginan orang tua menyekolahkan anak dekat rumah; (2) Keinginan orang tua terhadap penanaman agama sejak dini; dan (3) Keinginan orang tua untuk mendapatkan pendidikan yang baik dengan biaya yang terjangkau.

Dari hasil analisis data diperoleh kesimpulan tentang alasan dari ketiga keinginan orang tua wali murid menyekolahkan di KB Aisyiyah 30 Surabaya, yaitu: (1) jarak lokasi rumah dan sekolah yang dekat memudahkan bagi orang tua maupun siswa itu sendiri ketika pergi menuju lokasi sekolah maupun kemudahan dalam memantau proses pembelajaran di sekolah; penanaman pendidikan agama sejak usia dini sangat penting dalam pembentukan akhlak anak serta pembiasaan melakukan ibadah serta pemahaman terhadap hafalan doadoa pendek yang dapat diterapkan dirumah memudahkan orang tua untuk terus menstimulasi anak dalam pemahaman agama; (3) setiap orang tua atau wali murid memiliki keinginan untuk dapat menyekolahkan anaknya di kelompok bermain yang terbaik dengan pembiayaan yang terjangkau, fleksibel dan sesuai dengan kemampuan perekonomian yang bisa dilakukan oleh keluarga tersebut sesuai dengan buget yang telah dipersiapkan sebelumnya.

\section{PEMBAHASAN}

Dari hasil observasi yang dilakukan oleh peneliti terhadap teori-teori dan temuan sebelumnya serta penjelasan dan temuan yang dilakukan dilapangan dapat dijelaskan tentang pengelolaan di KB Aisyiyah 30 Surabaya dan motivasi orang tua dalam menyekolahkan di KB Aisyiyah 30 Surabaya.

Pengelolaan yang dilakukan di KB Aisyiyah 30 Surabaya menjadikan perhatian bagi pengelola sekolah dalam kemajuan perkembangan sekolah tersebut, diantaranya : (1) Komunikasi terbuka; (2) Kebutuhan guru dan siswa diperhatikan; (3) Adanya keterpaduan antara sekolah dan masyarakat.

Motivasi orang tua dalam menyekolahkan di KB Aisyiyah 30 Surabaya adalah sebagai berikut : (1) Keinginan orang tua yang ingin menyekolahkan anak dekat rumah; (2) Keinginan orang tua terhadap penanaman agama sejak dini; (3) Keinginan orang tua untuk mendapatkan pendidikan yang baik tetapi dengan biaya yang terjangkau. 
Motivasi orang tua yang
ingin menyekolahkan anak dekat
rumah senada dengan beberapa teori (2016: 2.21) menjelaskan bahwa mekanisme pendirian lembaga PAUD secara umum dan prinsip hampir sama antara satu dinas pendidikan nasional kota/kabupaten satu dengan yang lainnya. Persyaratan pokok yang harus disiapkan dalam pendirian yaitu : (1) Surat domisili, termasuk lokasi TK/PAUD yang didirikan; (2) Program kerja TK/PAUD selama satu tahun pelajran.; (3) Surat persetujuan masyarakat setempat melalui pengantar RT atau RW; (4) Surat rekomendasi lurah;

Rekomendasi dinas pendidikan kecamatan.; (6) Rekomendasi camat dari kecamatan setempat.; (7) Akte yayasan penyelenggara.

Senada dengan motivasi orang tua terhadap penanaman agama sejak dini, Hidayat (2014: 6.7-6.8) menjelaskan bahwa ada beberapa faktor yang dapat mempengaruhi perkembangan nilainilai keagamaan pada diri anak, yaitu: faktor pembawaan (internal) dan faktor lingkungan (eksternal). Adapun motivasi orang tua untuk mendapatkan pendidikan yang baik tetapi dengan biaya yang terjangkau, didukung dengan sebuah teori dari Elham Cahyantoro (dalam Hapidin, dkk, 2016: 6.2) mengungkapkan tentang prinsip-prinsip manajemen keuangan, yaitu: (1) Sumber dana pendidikan di TK/PAUD tidak sedikit, tidak hanya dari pemerintah atau yayasan yang menaunginya; (2) Dana pendidikan yang tersedia harus dimanfaatkan secara efektif dan efesien; (3) Semua menajemen keuangan dijaga hendaknya didasarkan pada peraturan perundang-undangan keuangan yang berlaku sehingga dapat dipertanggungjawabkan;

Pelaksanaan manajemen keuangan di TK/PAUD merupakan tanggungjawab kepala taman kanakkanak.

\section{KESIMPULAN}

Berdasarkan penelitian lapangan yang penulis lakukan di Kelompok Bermain Aisyiyah 30 Dukuh Bulak Banteng Kelurahan Bulak Banteng Kecamatan Kenjeran Kota Surabaya, tentang motivasi orang tua menyekolahkan anak di kelompok bermain, maka penulis dapat menarik kesimpulan sebagai berikut:

1. Pengelolaan di KB Aisyiyah 30 Surabaya dimulai dengan komunikasi yang terjalin baik diantara para pemegang kebijakan dalam mengambil keputusan akan merasa lebih positif mengenai sekolah, sehingga akan menciptakan pondasi yang kuat untuk pengembangan sekolah melalui peran serta masyarakat sekolah. Kebutuhan guru dan siswa diperhatikan sehingga pengembangan pembelajaran bisa berjalan dengan lancar. Adanya keterpaduan antara 
sekolah dan masyarakat sehingga akan terjalin interaksi yang baik diantara sekolah dan masyarakat.

2. Motivasi orang tua memilih sekolah untuk anak usia dini di Kelompok Bermain Aisyiyah 30 Surabayadikarenakan:

a. Mencari lokasi yang dekat rumah sehingga memudahkan orangtua untuk dapat mengantar, menjemput, mudah berkomunikasi dengan guru dan dapat ditempuh dengan berjalan kaki;

b. Keinginanpenanaman agama sejak dini sehingga anak dapat menguasai doa sehari-hari, hafal al-Qur'an surat-surat pendek juz 30, berakhlak mulia, memiliki sopan santun, berbakti kepada orang tua dan tumbuh menjadi generasi qur'ani;

c. Keinginan mendapatkan pendidikan yang baik tetapi dengan biaya terjangkau. $\mathrm{Di} \quad \mathrm{KB}$ Aisyiyah 30 pelayanannya memuaskan, memiliki fasilitas mewadai, pembelajarannya tidak kalah dengan KB yang ada di sekitar sekalipun pembiayaan pendidikannya relatif ringan, murah, fleksibel, dan sesuai dengan kondisi ekonomi warga Bulak Banteng.

\section{DAFTAR PUSTAKA}

Aryanti, Yuni. (2015). Motivasi Orang Tua Memasukkan Anaknya ke Taman KanakKanak. Bandung: Universitas Pendidikan Indonesia.

Azwar, Saifuddin. (2007). Metode Penelitian. Yogyakarta: Pustaka Pelajar.

Baihaqi. (2000). Mendidik Anak Dalam Kandungan. Jakarta: Darul Ulum Press.

Dwi Saputri, Endang. (2016). Motivasi Orang tua Dalam Memilih Paud Ditinjau Dari Profil Lembaga Pendidikan. Semarang: Universitas Negeri Semarang.

Danim, Sudarwan. (2002). Menjadi Peneliti Kualitatif. Bandung: Pustaka Setia.

Dayun Riadi, Nurlaili, \& Junaidi Hamzah. (2017). Ilmu Pendidikan Islam. Yogyakarta: Pustaka Pelajar.

Gunarti Winda, dkk. (2014). Metode Pengembangan Perilaku dan Kemampuan Dasar Anak Usia Dini. Tangerang Selatan-Banten: Universitas Terbuka-Kementerian Pendidikan dan Kebudayaan. Hapidin, dkk. (2016). Manajemen Pendidikan TK/PAUD. Tangerang Selatan-Banten: Universitas TerbukaKementerian Riset, Teknologi, dan Pendidikan Tinggi.

Hidayat, Satibi, Otib. (2014). Metode Pengembangan Moral \& 
Nilai-nilai Agama. Tangerang

Selatan-Banten: Universitas

Terbuka-Kementerian

Pendidikan dan Kebudayaan.

Hildayani, Rini. (2014). Materi

Pokok Psikologi

Perkembangan Anak: 1-12

PAUD4104. Tangerang

Selatan: Universitas Terbuka.

Isro'un Nikmah, Ninik. (2008).

Motivasi Orang Tua Memilih

Kelompok Bermain Sebagai

Alternatif Pendidikan Anak

Usia Dini. Malang:

Universitas Islam Negeri

Malang.

J.Moleong, Lexy. (2007).

Metodologi Penelitian

Kualitatif. Bandung: Remaja

Rosdakarya.

Mulyani, Novi. (2018).

Perkembangan Dasar Anak
Usia Dini. Yogyakarta: Gava Media.

Narbuko, Cholid \& Achmadi, Abu. (2007). Metodologi Penelitian. Jakarta: Bumi Aksara.Nasution. (2007). Metode Research. Jakarta: Bumi Aksara.

Nugraha Ali, Zaman Badru, \& Dwiyana Dina. (2014). Materi Pokok Program Pelibatan Orang Tua dan Masyarakat: $\quad$ 1-12 PAUD4502. Tangerang Selatan: Universitas Terbuka

Sujdana, Nana \& Ibrahim. (2007). Penelitian dan Penilaian Pendidikan. Bandung: Sinar Baru Algensindo. 